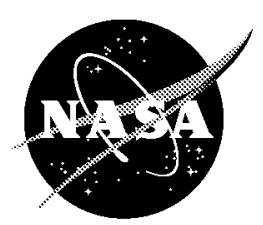

\title{
Validation of International Space Station Electrical Performance Model via On-Orbit Telemetry
}

\author{
Anthony G. Jannette \\ Analex Corporation, Cleveland, Ohio \\ Jeffrey S. Hojnicki, David B. McKissock, James Fincannon, \\ Thomas W. Kerslake, and Carlos D. Rodriguez \\ Glenn Research Center, Cleveland, Ohio
}


The NASA STI Program Office ... in Profile

Since its founding, NASA has been dedicated to the advancement of aeronautics and space science. The NASA Scientific and Technical Information (STI) Program Office plays a key part in helping NASA maintain this important role.

The NASA STI Program Office is operated by Langley Research Center, the Lead Center for NASA's scientific and technical information. The NASA STI Program Office provides access to the NASA STI Database, the largest collection of aeronautical and space science STI in the world. The Program Office is also NASA's institutional mechanism for disseminating the results of its research and development activities. These results are published by NASA in the NASA STI Report Series, which includes the following report types:

- TECHNICAL PUBLICATION. Reports of completed research or a major significant phase of research that present the results of NASA programs and include extensive data or theoretical analysis. Includes compilations of significant scientific and technical data and information deemed to be of continuing reference value. NASA's counterpart of peerreviewed formal professional papers but has less stringent limitations on manuscript length and extent of graphic presentations.

- TECHNICAL MEMORANDUM. Scientific and technical findings that are preliminary or of specialized interest, e.g., quick release reports, working papers, and bibliographies that contain minimal annotation. Does not contain extensive analysis.

- CONTRACTOR REPORT. Scientific and technical findings by NASA-sponsored contractors and grantees.
- CONFERENCE PUBLICATION. Collected papers from scientific and technical conferences, symposia, seminars, or other meetings sponsored or cosponsored by NASA.

- SPECIAL PUBLICATION. Scientific, technical, or historical information from NASA programs, projects, and missions, often concerned with subjects having substantial public interest.

- TECHNICAL TRANSLATION. Englishlanguage translations of foreign scientific and technical material pertinent to NASA's mission.

Specialized services that complement the STI Program Office's diverse offerings include creating custom thesauri, building customized data bases, organizing and publishing research results ... even providing videos.

For more information about the NASA STI Program Office, see the following:

- Access the NASA STI Program Home Page at http://www.sti.nasa.gov

- E-mail your question via the Internet to help@sti.nasa.gov

- Fax your question to the NASA Access Help Desk at 301-621-0134

- Telephone the NASA Access Help Desk at 301-621-0390

- Write to: NASA Access Help Desk NASA Center for AeroSpace Information 7121 Standard Drive Hanover, MD 21076 


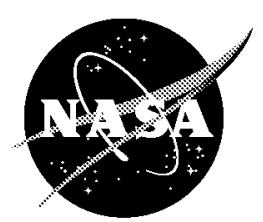

\section{Validation of International Space Station Electrical Performance Model via On-Orbit Telemetry}

Anthony G. Jannette

Analex Corporation, Cleveland, Ohio

Jeffrey S. Hojnicki, David B. McKissock, James Fincannon,

Thomas W. Kerslake, and Carlos D. Rodriguez

Glenn Research Center, Cleveland, Ohio

Prepared for the

37th Intersociety Energy Conversion Engineering Conference

sponsored by the Institute of Electrical and Electronics Engineers,

Electron Devices Society

Washington, DC, July 28-August 2, 2002

National Aeronautics and

Space Administration

Glenn Research Center

July 2002 


\section{Acknowledgments}

This validation is the culmination of a decade-long effort to develop an EPS model that provides a valuable resource to the ISS program. Many people made numerous contributions to this effort. Although there is no way to acknowledge everyone, the authors wish to recognize: Michelle Northcutt for gathering large amounts of on-orbit data and running SPACE for many of these analyses; Ann Delleur for reviewing this paper and performing so many ISS quick-turnaround analyses, thus allowing the authors to complete this work; Robert Hill, Augustina Han, Ken Metcalf, and Gyan Hajela of the Boeing Corporation along with Tom Miller, Danny Irvine, and the BSAM team for their companion modeling efforts; and James Dunn, Bill Spetch, and Tim Propp of the ISS Program Office for their help and support over the years.

Available from

NASA Center for Aerospace Information 7121 Standard Drive

Hanover, MD 21076
National Technical Information Service 5285 Port Royal Road Springfield, VA 22100

Available electronically at http://gltrs.gronasa.gog 
IECEC 2002 Paper No. 20007

\title{
VALIDATION OF INTERNATIONAL SPACE STATION ELECTRICAL PERFORMANCE MODEL VIA ON-ORBIT TELEMETRY
}

\author{
Anthony G. Jannette \\ Analex Corporation \\ 1100 Apollo Drive \\ Cleveland, $\mathrm{OH} 44142$ \\ Phone: 216-433-2818 \\ FAX: 216-433-2995 \\ Anthony.Jannette@grc.nasa.gov
}

\author{
Jeffrey S. Hojnicki, David B. McKissock, James Fincannon, \\ Thomas W. Kerslake, Carlos D. Rodriguez \\ National Aeronautics and Space Administration \\ Glenn Research Center \\ 21000 Brookpark Road \\ Cleveland, $\mathrm{OH} 44135$
}

\begin{abstract}
The first U.S. power module on International Space Station (ISS) was activated in December 2000 Comprised of solar arrays, nickel-hydrogen $\left(\mathrm{NiH}_{2}\right)$ batteries and a direct current power management and distribution (PMAD) system, the electric power system (EPS) supplies power to housekeeping and user electrical loads. Modeling EPS performance is needed for several reasons, but primarily to assess near-term planned and off-nominal operations, and because the EPS configuration changes over the life of the ISS. The System Power Analysis for Capability Evaluation (SPACE) computer code is used to assess the ISS EPS performance.

This paper describes the process of validating the SPACE EPS model via ISS on-orbit telemetry. To accomplish this goal, telemetry was first used to correct assumptions and component models in SPACE. Then on-orbit data was directly input to SPACE to facilitate comparing model predictions to telemetry. It will be shown that SPACE accurately predicts on-orbit component and system performance. For example, battery state-of-charge was predicted to within 0.6 percentage points over a 0 to $100 \%$ scale, and solar array current was predicted to within a root mean square (RMS) error of 5.1 Amps out of a typical maximum of 220 Amps. First, SPACE model predictions are compared to telemetry for the ISS EPS components: solar arrays, $\mathrm{NiH}_{2}$ batteries, and the PMAD system. Second, SPACE predictions for the overall performance of the ISS EPS are compared to telemetry and again demonstrate model accuracy.
\end{abstract}

\section{INTRODUCTION}

NASA Glenn Research Center has, over the past decade, developed a computer code called SPACE
(Hojnicki et al, 1993; Fincannon et al, 1996; Kerslake et al, 1993). Historically, ISS EPS performance requirements were verified using this and other computer models since size and scope prevented a complete end-to-end system test. SPACE has been used for numerous ISS EPS assessments (e.g. Space Station Redesign Team, 1993).

SPACE is a detailed, integrated model that can be run in a load-driven mode to verify that the EPS can satisfy a pre-defined mission timeline. Model inputs include time varying and distributed electrical load profiles, EPS architecture, solar beta angle, vehicle attitude, and solar array pointing. SPACE models each ISS EPS channel independently, as shown in Figure 1. In the sunlit portion of the orbit, power flows from the solar array through the Sequential Shunt Unit (SSU), to the DC Switching Unit (DCSU). Power then flows downstream to loads connected to the DC-DC Converter Units (DDCU), and to the batteries through the Battery Charge Discharge Unit (BCDU).

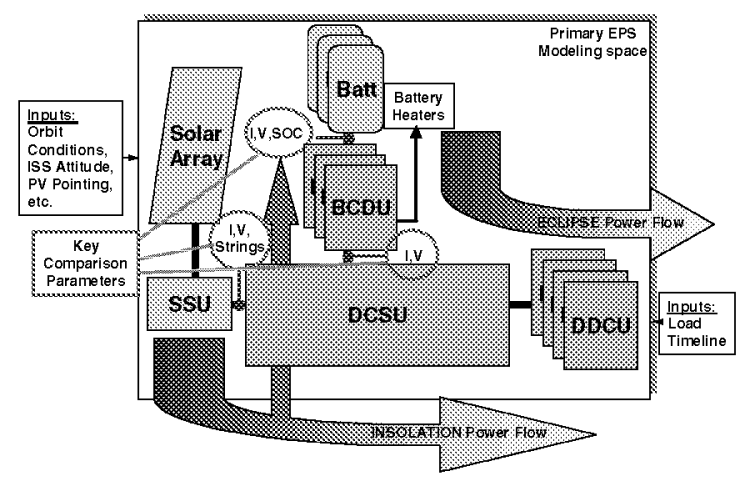

FIGURE 1. ISS EPS OVERVIEW 
During eclipse periods, and during sun periods with low solar array output, power flows out of the batteries through the BCDU to the DCSU, which routes power to loads connected to DDCUs installed inside and outside the pressurized modules on the ISS. The temperatures of the batteries and electronics are maintained via a thermal control system (not shown). Currently, there are two U.S. power channels installed on ISS. Each contains one solar array wing, one SSU, one DCSU, three BCDUs, and three batteries. The channels are designated $2 \mathrm{~B}$ and $4 \mathrm{~B}$.

To validate the SPACE component models, selected parameters were obtained from the telemetry and compared with model predictions. For example, for the converter units (BCDU and DDCU), current and voltage telemetry from the nearest upstream and downstream points were used to estimate converter efficiency. The following summarizes efforts to validate the solar array, battery and PMAD modules of SPACE, as well as overall system performance.

\section{SOLAR ARRAY VALIDATION}

The SPACE solar array model is a bi-facial model since the ISS array can produce power from both front and back surfaces (Delleur et al, 1999, Delleur and Kerslake 2002). Illumination can come from direct solar illumination and from Earth albedo. An array similar to the ISS array was operated on the space station Mir, from May 1996 to November 1998, in joint Russian and U.S. effort. This test provided confidence that the hardware would meet performance criteria (Kerslake and Hoffman, 1997, 1999). ISS telemetry has further validated the SPACE solar array model.

Figure 2 considers the condition with direct solar illumination on the array front side and compares telemetry array output current to two predictions from SPACE. Total array current was obtained by combining the SSU output and shunt currents. The first prediction accounted only for direct solar illumination (dashed line) and under predicted array current by as much as $30 \mathrm{Amps}$ ( $14 \%$ error). Including current from Earth albedo resulted in much better agreement with telemetry (solid line) (4\% error).

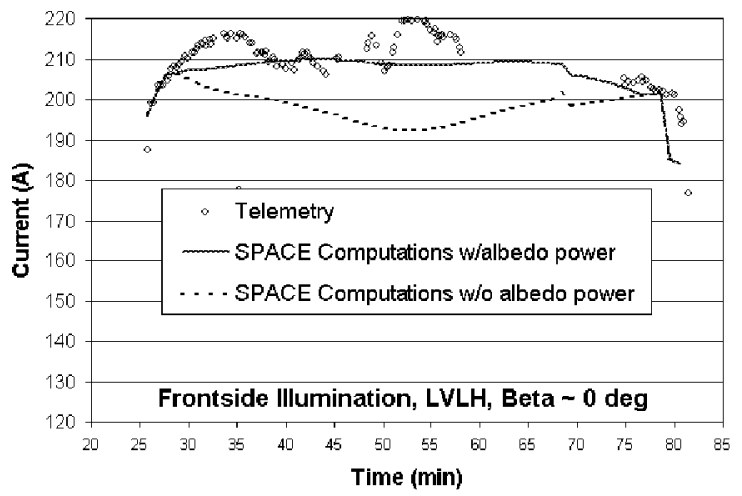

FIGURE 2. ARRAY FRONT SIDE PERFORMANCE

Note there is a $10 \mathrm{Amp}$ ripple in the telemetry. If temperature effects were used to explain the ripple, the solar array wing temperature would have to change about $50^{\circ} \mathrm{C}$ in 5 minutes, which is unlikely. Variable albedo illumination conditions can account for this ripple, which requires approximately a doubling of albedo, from the nominal value of 0.27 to 0.54 . This is a reasonable change for ocean-cloudland mass transitions. Based on GOES-10 satellite imagery, such transitions were indeed present along the ISS ground track for this orbit. This example serves to validate the front side illumination section of SPACE and confirms the need to account for Earth albedo illumination on the solar array in the model.

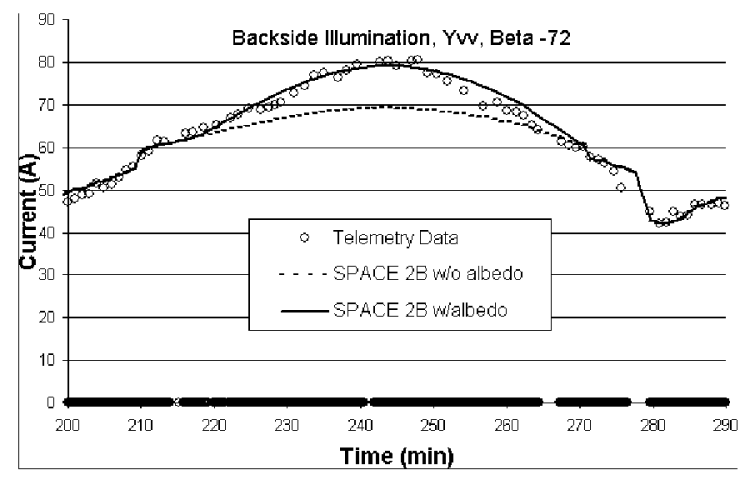

FIGURE 3. ARRAY BACKSIDE PERFORMANCE

Figure 3 demonstrates the model fidelity for a case in which the backside of a solar array received direct solar illumination. On January 5, 2001 one of two solar arrays on-orbit was directed to point its backside to the sun. As in the previous example, SPACE was run twice, once to account for direct backside illumination only, and second to include Earth albedo. Without albedo (dashed line), SPACE under predicted array current by 10 Amps (13\% error). With Earth albedo (solid line) SPACE prediction closely followed telemetry. This again confirms the bi-facial nature of ISS solar arrays and the accuracy of SPACE.

\section{ENERGY STORAGE VALIDATION}

The SPACE battery model utilizes empirical algorithms developed by the ISS battery vendor, Space Systems Loral. Input data for the algorithms consists of individual $\mathrm{NiH}_{2}$ cell data at temperatures of $0^{\circ}, 10^{\circ}$, and $20^{\circ} \mathrm{C}$, states-of-charge (SOCs) of $80 \%$, $65 \%$, and $40 \%$, and beginning and end of life. Battery voltage is determined by the battery current, SOC, temperature, and age.

Figures 4 and 5 compare the SPACE battery model with telemetry. An eclipse period begins in the lower right corner. The voltage falls during the eclipse period as the battery discharges, then increases in the sun period during charging, until an SOC is reached where the control system reduces the charge current. Figure 4 represents one of three batteries on channel $2 \mathrm{~B}$, on the $101^{\text {st }}$ day of 2001 . Note that the model consistently over predicted charge and discharge voltages. A second comparison used telemetry from a different day (2001, day 136) and channel (4B) as inputs to the model. In this case, 
SPACE under predicted charge voltages and only slightly over predicted discharge voltages. Although predictions correlate well with telemetry (within approximately $5 \%$ ), the discharge voltage predictions consistently exceed on-orbit data. Modelers prefer to err on the side of conservatism by slightly underpredicting discharge voltage.

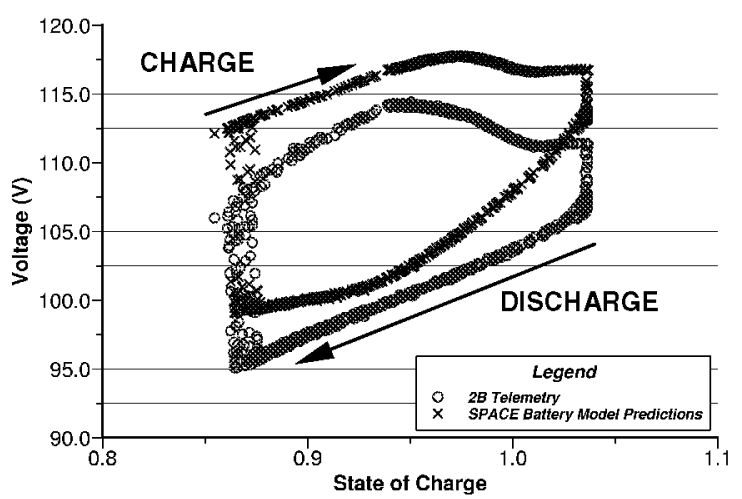

FIGURE 4. CHANNEL 2B BATTERY VOLTAGE, $0^{\circ} \mathrm{C}$

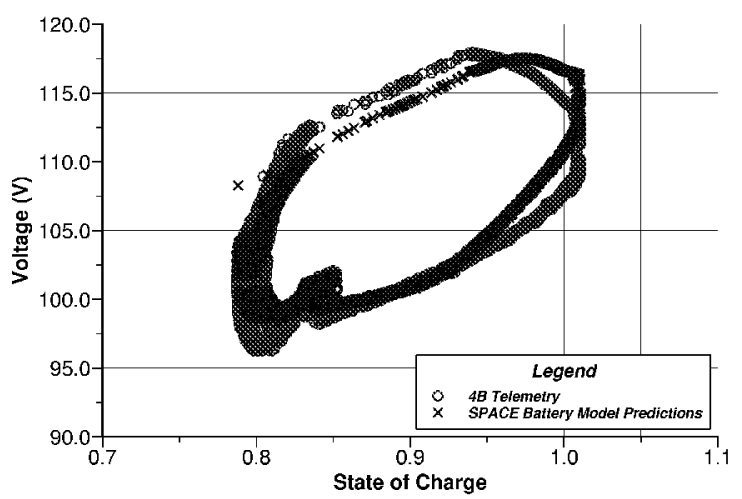

FIGURE 5. CHANNEL 4B BATTERY VOLTAGE, $0^{\circ} \mathrm{C}$

Figure 6 shows the same case as figure 4 , reanalyzed with a $10^{\circ}$ battery temperature. Though telemetry indicates that the thermal control system maintains battery temperature between $1^{\circ} \mathrm{C}$ and $2.5^{\circ} \mathrm{C}$, modeling a $10^{\circ} \mathrm{C}$ temperature resulted in a prediction that more closely matched on-orbit data, especially end-of-charge voltage.

The data set from Loral was compared to test data from the Naval Surface Warfare Center in Crane, Indiana, where ISS $\mathrm{NiH}_{2}$ cells are undergoing orbital life cycle testing at $65 \%$ and $10^{\circ} \mathrm{C}$. ISS cells were also tested at Crane at $40 \%$ minimum SOCs and $10^{\circ} \mathrm{C}$. Figure 7 shows a comparison of the measured cell charge and discharge voltages in the Loral and Crane data sets for $65 \%$ SOC. Noting that the Crane data had a lower end-of-discharge voltage, the Crane charge and discharge data were implemented in the SPACE battery model for both $65 \%$ and $40 \%$ SOC. Crane data did not include an $80 \%$ SOC curve, so the Loral $80 \%$ SOC voltage curve was included, after some tuning, to better match on-orbit performance. In order to make all three curves consistent, the $10^{\circ} \mathrm{C}$
Loral curve was used. Voltage, current, and SOC comparisons between on-orbit data and this latest version of the SPACE battery model are shown in the system comparisons section.

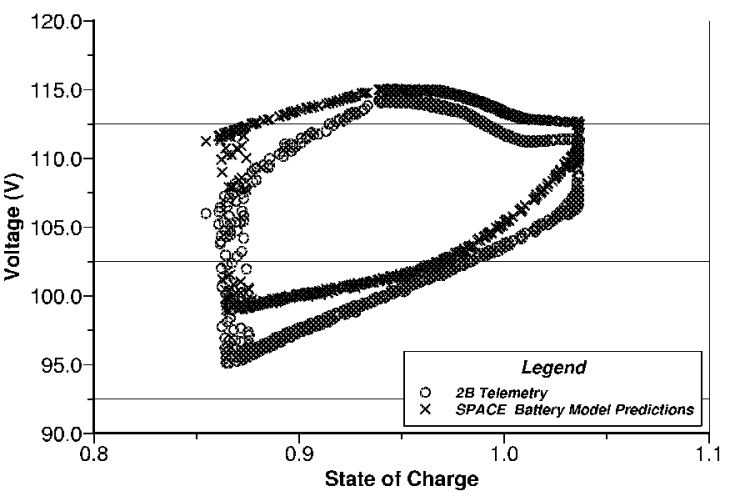

FIGURE 6. CHAN. 2B BATTERY VOLTAGE, $10^{\circ} \mathrm{C}$

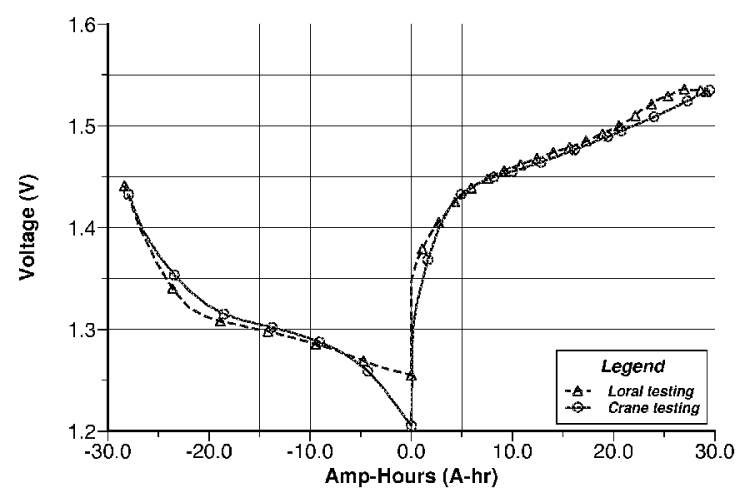

FIGURE 7. TEST DATA AT $65 \%$ SOC, $10^{\circ} \mathrm{C}$

\section{PMAD PERFORMANCE VALIDATION}

Battery power is routed through and controlled by BCDUs. When that power is sent downstream to loads, it passes through a DDCU. As the BCDU and DDCU are the largest contributors to electrical losses in the system, each was examined closely. Both the BCDU and DDCU contain a power converter with an efficiency that varies with load. The efficiencies of the various DDCUs can be characterized by one curve. For BCDUs, though, there are two unique efficiencies, one for battery charging and one for discharge.

\section{Sensor Calibration Requirements}

Initial inspection of telemetry for BCDUs showed questionable sensor data. In particular, two current sensors in series on the battery side of the BCDU did not correlate. Because the readings sometimes were consistently offset, sensor inaccuracy was indicated. Acceptance test data were examined to see if the sensors had exhibited similar behavior on the ground. Ambient temperature tests (which most closely matched on-orbit BCDU temperatures) showed similar offsets between the two current sensors. Figure 8 shows the difference between the two current sensors for a typical BCDU. Since the test 
data provided both sensor readings and digital multimeter readings, calibration formulae could be derived. These formulae were applied to the on-orbit BCDU current telemetry to enhance its accuracy.

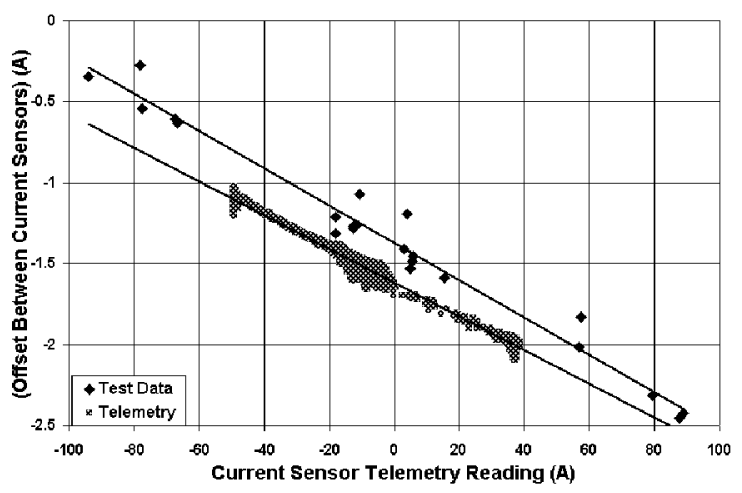

FIGURE 8. SAMPLE BCDU SENSOR OFFSETS

In general, voltage sensor readings are stable and accurate. In contrast, each current sensor for each BCDU has its own calibration relationship that varies with current. Figure 9 shows the calibration curves for the battery-side current sensors (those nearest the battery) where the actual values are derived from the digital multimeter. In general, the curves are linear. Calibration formulae are essential to derive the BCDU efficiency from on-orbit data. For one BCDU in particular, the current sensor on the power system side of the converter was behaving in what appeared to be a degraded manner (i.e. calibration was not possible). In this case, the current sensor reading from the DCSU was used to replace that of the BCDU and enabled BCDU efficiencies to be derived.

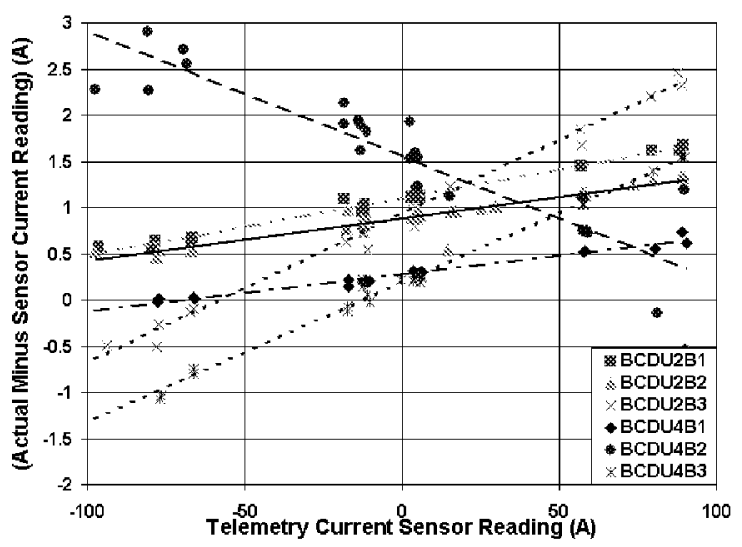

FIGURE 9. BCDU SENSOR CALIBRATION

\section{Derived BCDU/DDCU Efficiency Characteristics}

Application of the calibration formulae to each BCDU sensor enabled the derivation of BCDU efficiencies, which were similar for all BCDUs. Since operations to date have only covered a portion of the BCDU operating envelope, a complete efficiency curve cannot be derived from telemetry. Ground test data do cover the entire operating range. As telemetry showed excellent agreement with the acceptance test mode \#2 (ATM \#2, high battery voltage, low source voltage), this justified using test data for BCDU efficiency outside the range of on-orbit data. Figure 10 compares the BCDU efficiency assumed prior to onorbit operation to: ATM \#2 results and calibrated onorbit results, both averaged for all BCDUs.

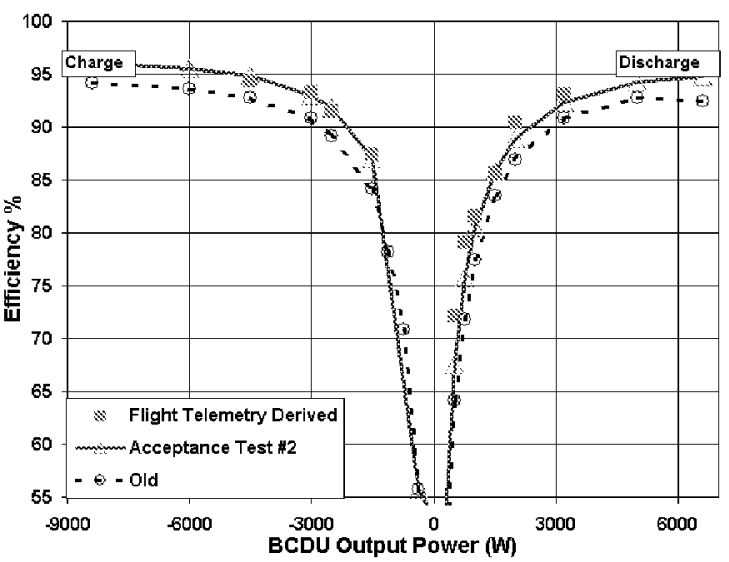

FIGURE 10. BCDU EFFICIENCIES

All on-orbit DDCUs were studied for their efficiencies. Results indicated similar characteristics among all of them. Therefore, one load dependent efficiency curve was derived. The curve was then applied to all DDCU telemetry in order to generate accurate on-orbit electrical loads to use as inputs to SPACE for validation of the model against telemetry.

\section{SYSTEM PERFORMANCE COMPARISONS}

After updating the model with validated EPS component data, several systems comparisons were performed, each analyzing a 24 hour period. Model inputs were obtained from the telemetry data and included: electrical load demand, vehicle attitude, solar array pointing, orbital conditions, initial battery SOC (beginning of eclipse was chosen as the starting point for all analyses) and battery heater activity.

The telemetry was processed and input to SPACE. The model was then run to predict the state of the EPS in response to these inputs for the 24 hour period. The response included battery SOCs, currents and voltages throughout the system, and the number of unshunted solar array circuits. Results were quantitatively compared to telemetry by calculating the RMS differences, and qualitatively examined by graphically overlaying the telemetry and predictions.

\section{Sample Case}

A comparison performed for the $136^{\text {th }}$ day of 2001 provides an example. On this day the solar arrays were not actively tracking the sun, but were in a fixed or 'directed position.' This resulted in direct solar illumination on the backside of the solar arrays for the first part of each sun period, and enabled the bi-facial solar array model to be validated. The ISS was in an attitude fixed with respect to the Earth, with a small yaw $\left(-10^{\circ}\right)$ and pitch $\left(-8^{\circ}\right)$. The solar $B$ angle was 
near zero, and altitude averaged 210 nautical miles.

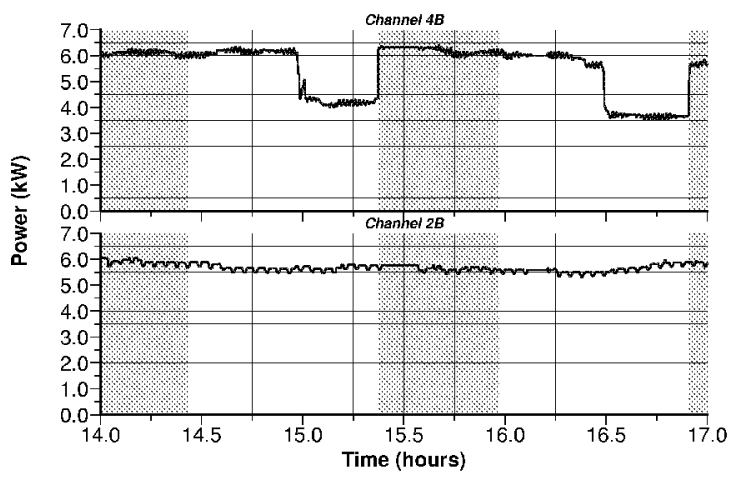

FIGURE 11. ELECTRICAL LOAD DEMAND

Figure 11 shows the electrical load demand on the two EPS channels. The shaded regions represent the eclipse periods, and the light regions the sun periods. The remainder of this presentation will focus on one power channel, $2 \mathrm{~B}$, as comparison results are similar for channel 4B (see table 1). Also, although the entire 24 hour period was assessed, a three hour segment, 14 to 17 hours, shows the comparisons more clearly.

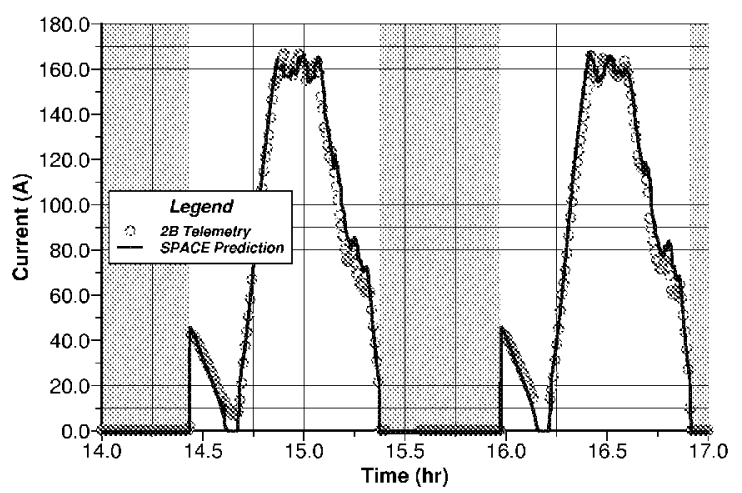

FIGURE 12. CHANNEL 2B SSU CURRENT

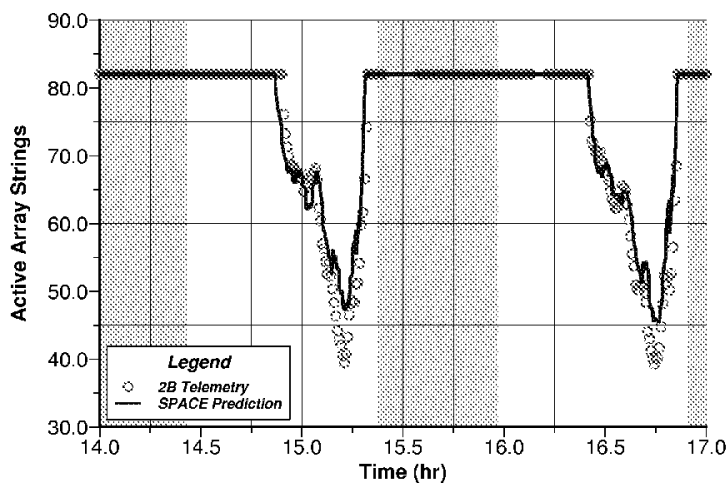

FIGURE 13. CHAN. 2B ACTIVE ARRAY STRINGS

SSU output current is shown in Figure 12 and demonstrates array-to-sun pointing conditions with a fixed gimbal. At orbit dawn, the backside of the solar array receives direct solar illumination for 12 minutes, with its maximum value at orbital sunrise. SSU current then decreases with decreased backside illumination and edge-on conditions. This is followed by a sharp increase as the front side of the solar array receives direct solar flux. SSU current then falls as the batteries reach full charge and strings on the SSU are increasingly shunted (figure 13). Through the entire sun period, SPACE has an RMS error of 5.1 Amps and 2.7 active SSU strings compared to telemetry.

Figures 14 through 17 compare SPACE predictions for the BCDU and battery. In figure 14, SPACE slightly over predicted BCDU current during the eclipse periods (3.8 Amps RMS). In the sun periods, as the magnitudes of current were three times greater than in eclipse, it is not surprising to find the error to be higher as well (8.3 Amps RMS). The reader will note variability in values in figures 12 and 14 around 15 hours. This is due to battery heater activity as the number of heaters providing heat to the batteries varied between 0 and 5 in a span of 15 minutes ( $380 \mathrm{~W}$ load per battery heater).

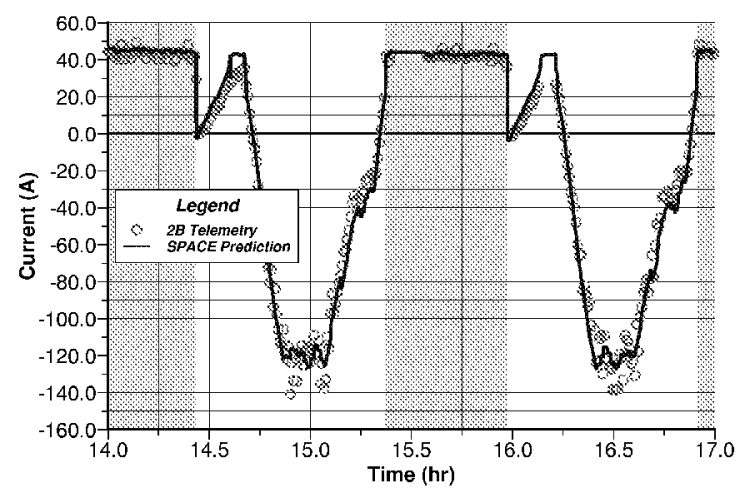

\section{FIGURE 14. CHAN. 2B TOTAL BCDU CURRENT}

Figure 15 displays battery current predictions from SPACE and on-orbit data. RMS error in both eclipse and sun are higher than those for the BCDU. Battery voltage in Figure 16 shows the result of implementing Crane battery data into SPACE; end-of-discharge voltage is now slightly under-predicted by the model.

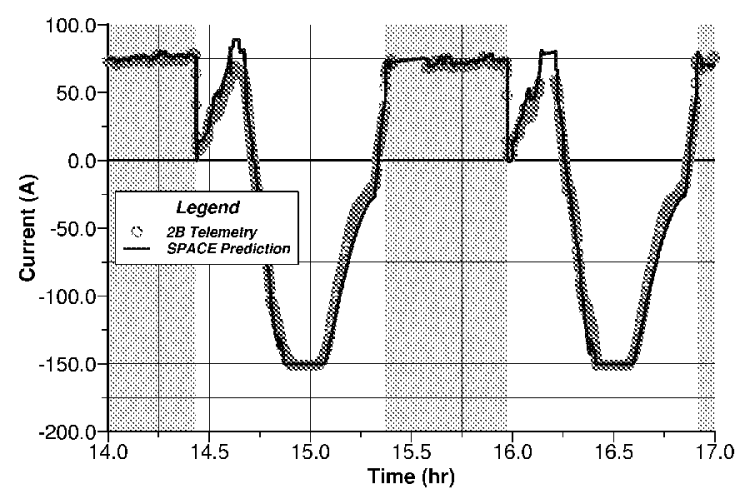

FIGURE 15. CHAN 2B TOTAL BATTERY CURRENT 


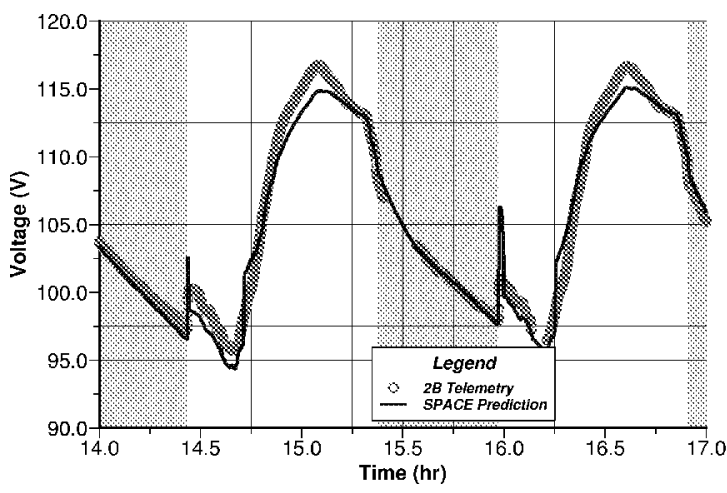

FIGURE 16. CHAN. 2B AVG. BATTERY VOLTAGE

Finally, figure 17 compares SPACE predictions for battery SOC to on-orbit data. ISS operators use battery SOC to judge the state of the EPS as a whole, making it the most critical parameter to predict accurately. SPACE slightly under predicted SOC, with a 0.6 percentage point error over the time period.

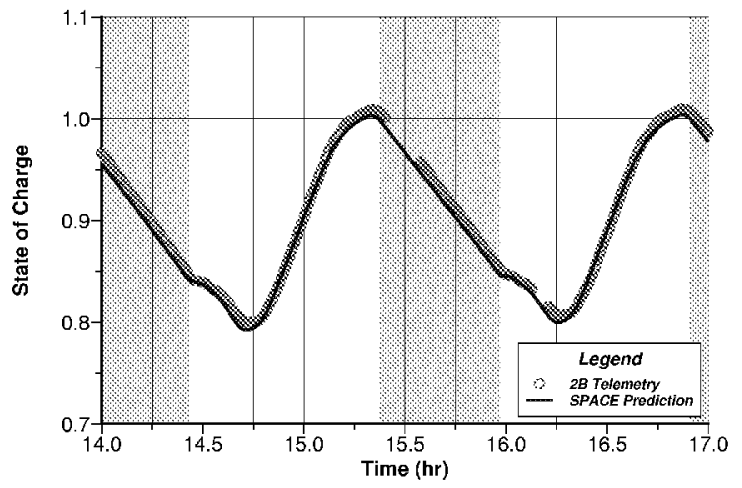

FIGURE 17. CHANNEL 2B BATTERY SOC

TABLE 1. RMS ERRORS

\begin{tabular}{|c|l|c|c|}
\hline \multicolumn{4}{|c|}{ 2001, Dav 136 } \\
\hline ORU & \multicolumn{1}{|c|}{ Parameter } & Ch 2B & Ch 4B \\
\hline \multirow{3}{*}{ SSU } & Current & $5.1 \mathrm{~A}$ & $5.4 \mathrm{~A}$ \\
\cline { 2 - 4 } & Voltage & $1.0 \mathrm{~V}$ & $0.8 \mathrm{~V}$ \\
\cline { 2 - 4 } & Active Strings & 2.7 & 2.7 \\
\hline \multirow{3}{*}{ BCDU } & Current (discharge) & $3.8 \mathrm{~A}$ & $3.2 \mathrm{~A}$ \\
\cline { 2 - 4 } & Current (charge) & $8.3 \mathrm{~A}$ & $6.9 \mathrm{~A}$ \\
\cline { 2 - 4 } & Voltage (all times) & $1.3 \mathrm{~V}$ & $1.2 \mathrm{~V}$ \\
\hline \multirow{4}{*}{ Battery } & $0.6 \mathrm{P} . \mathrm{P}$ & $0.7 \mathrm{P} . \mathrm{P}$. \\
\cline { 2 - 4 } & SOC & $6.7 \mathrm{~A}$ & $5.7 \mathrm{~A}$ \\
\cline { 2 - 4 } & Current (discharge) & $9.7 \mathrm{~A}$ & $9.7 \mathrm{~A}$ \\
\cline { 2 - 4 } & Voltage (all times) & $1.1 \mathrm{~V}$ & $1.5 \mathrm{~V}$ \\
\hline
\end{tabular}

\section{CONCLUDING REMARKS}

The SPACE computer model is designed to accurately predict performance of the ISS EPS, particularly in response to time-varying electrical loads, vehicle attitude. Nine 24 hour periods of onorbit operations, covering a wide solar beta range $\left(-26^{\circ}\right.$ to $\left.+40^{\circ}\right)$ and time span (four months), were modeled by SPACE. This paper highlighted one 24 hour period, but each day showed similar results. The accuracy of SPACE was demonstrated via root mean square comparisons between predictions and on-orbit telemetry. Table 1 summarizes these comparisons. Efforts to validate SPACE will continue as more data becomes available from continuing EPS operations. Areas of future work include deriving calibrated onorbit DDCU efficiency, improving battery voltage predictions and quantifying performance degradation of solar arrays and batteries.

\section{REFERENCES}

Delleur, A.M., Kerslake, T.W., Scheiman, D.A. "Analysis of Direct Solar Illumination on the Backside of Space Station Solar Cells," NASA TM-1999209377, 34 $4^{\text {th }}$ IECEC, Vancouver, BC, August, 1999.

Delleur, A.M. and Kerslake, T.W., "Electrical Performance of the International Space Station U.S. Photovoltaic Array during Bifacial Illumination," $37^{\text {th }}$ IECEC, Washington D.C., July 28-August 2, 2002.

Fincannon, J., Delleur, A.M., Green, R.D., Hojnicki, J.S., "Load-Following Power Timeline Analyses for the International Space Station," NASA TM-107263, $31^{\text {st }}$ IECEC, Washington D.C., August, 1996.

Hojnicki, J.S., Green, R.D., Kerslake, T.W., McKissock, D.B., Trudell, J.J., "Space Station Freedom Electrical Performance Model," NASA TM$106395,28^{\text {th }}$ IECEC, Atlanta, GA, August, 1993.

Kerslake, T.W., Hojnicki, J.S., Green, R.D., Follo, J.C., "System Performance Predictions For Space Station Freedom's Electrical Power System," NASA TM-106396, 28 ${ }^{\text {th }}$ IECEC, Atlanta, GA, August, 1993.

Kerslake, T.W. and Hoffman, D.J., "Mir Cooperative Solar Array Flight Performance Data and Computational Analysis," NASA TM-1997-107502, July 1997.

Kerslake, T.W. and Hoffman, D.J., "Performance of the Mir Cooperative Solar Array After 2.5 Years in Orbit," NASA TM-1999-209287, July 1999.

Space Station Redesign Team Final Report to the Advisory Committee on the Redesign of the Space Station, June 1993. 


\begin{tabular}{|l|l|l|}
\hline 1. AGENCY USE ONLY (Leave blank) & $\begin{array}{c}\text { 2. REPORT DATE } \\
\text { July } 2002\end{array}$ & $\begin{array}{l}\text { 3. REPORT TYPE AND DATES COVERED } \\
\text { Technical Memorandum }\end{array}$ \\
\hline
\end{tabular}

\section{\begin{tabular}{l|l} 
4. TITLE AND SUBTITLE & 5. FUNDING NUMBERS
\end{tabular}}

Validation of International Space Station Electrical Performance Model Via On-Orbit Telemetry

\section{AUTHOR(S)}

WU-575-15-69-00

Anthony G. Jannette, Jeffrey S. Hojnicki, David B. McKissock, James Fincannon,

Thomas W. Kerslake, and Carlos D. Rodriguez

\section{PERFORMING ORGANIZATION NAME(S) AND ADDRESS(ES)}

National Aeronautics and Space Administration

John H. Glenn Research Center at Lewis Field

Cleveland, Ohio 44135-3191

\section{SPONSORING/MONITORING AGENCY NAME(S) AND ADDRESS(ES)}

National Aeronautics and Space Administration

Washington, DC 20546-0001
8. PERFORMING ORGANIZATION REPORT NUMBER

E-13498
10. SPONSORING/MONITORING AGENCY REPORT NUMBER

NASA TM-2002-211803

IECEC-2002-20007

\section{SUPPLEMENTARY NOTES}

Prepared for the 37th Intersociety Energy Conversion Engineering Conference sponsored by the Institute of Electrical and Electronics Engineers, Electron Devices Society, Washington, DC, July 28-August 2, 2002. Anthony G. Jannette, Analex Corporation, Cleveland, Ohio 44135; Jeffrey S. Hojnicki, David B. McKissock, James Fincannon, Thomas W. Kerslake, and Carlos D. Rodriguez, NASA Glenn Research Center. Responsible person, Anthony G. Jannette, organization code 6920, 216-433-2818.

\begin{tabular}{l|l} 
12a. DISTRIBUTION/AVAILABILITY STATEMENT & 12b. DISTRIBUTION CODE
\end{tabular}

Unclassified - Unlimited

Subject Category: 20

Distribution: Nonstandard

Available electronically at http://gitrs.grc.nasa.gov

This publication is available from the NASA Center for AeroSpace Information, 301-621-0390.

\section{ABSTRACT (Maximum 200 words)}

The first U.S. power module on International Space Station (ISS) was activated in December 2000. Comprised of solar arrays, nickel-hydrogen $\left(\mathrm{NiH}_{2}\right)$ batteries, and a direct current power management and distribution (PMAD) system, the electric power system (EPS) supplies power to housekeeping and user electrical loads. Modeling EPS performance is needed for several reasons, but primarily to assess near-term planned and off-nominal operations and because the EPS configuration changes over the life of the ISS. The System Power Analysis for Capability Evaluation (SPACE) computer code is used to assess the ISS EPS performance. This paper describes the process of validating the SPACE EPS model via ISS on-orbit telemetry. To accomplish this goal, telemetry was first used to correct assumptions and component models in SPACE. Then on-orbit data was directly input to SPACE to facilitate comparing model predictions to telemetry. It will be shown that SPACE accurately predicts on-orbit component and system performance. For example, battery state-of-charge was predicted to within 0.6 percentage points over a 0 to 100 percent scale and solar array current was predicted to within a root mean square (RMS) error of 5.1 Amps out of a typical maximum of 220 Amps. First, SPACE model predictions are compared to telemetry for the ISS EPS components: solar arrays, $\mathrm{NiH}_{2}$ batteries, and the PMAD system. Second, SPACE predictions for the overall performance of the ISS EPS are compared to telemetry and again demonstrate model accuracy.

14. SUBJECT TERMS

International Space Station; Electric power; Models; Proving; Performance prediction; Solar arrays; Energy storage

\begin{tabular}{|c|c|c|}
\hline $\begin{array}{c}\text { 17. SECURITY CLASSIFICATION } \\
\text { OF REPORT } \\
\text { Unclassified }\end{array}$ & $\begin{array}{c}\text { 18. SECURITY CLASSIFICATION } \\
\text { OF THIS PAGE } \\
\text { Unclassified }\end{array}$ & $\begin{array}{c}\text { 19. SECURITY CLASSIFICATION } \\
\text { OF ABSTRACT } \\
\text { Unclassified }\end{array}$ \\
\hline
\end{tabular}

